\title{
A tudomány legfőbb feladata növénytermelésünkben
}

\author{
ERDEI FERENC \\ földmúvelésügyi miniszter
}

Országunk kísérletügyi munkája elsősorban a növénytermelés és a növénynemesítés terén a régebbi időszakban sem volt eredménytelen. Nem egy kitünő régi kutatónk jelentős eredményt ért el és ezek kisebb-nagyobb mértékben a hazai termelésben is, de nem egy területen határainkon kívül is használatosak. Nem kevés és nem jelentéktelen tehát az a tapasztalat, ami e téren rendelkezésünkre áll és további feladataink megoldásánál eredményesen felhasználható. Mégis növénytermelésünk termelékenysége és általában termésátlagaink feltűnően és megengedhetetlenül alacsonyak. Egyetlen egy területe sincs növénytermelésünknek, ahol a termelékenységet és a terméshozamot olyan fokra sikerült volna emelni, ami megközelíti azokat a lehetőségeket, amelyeket a fejlett mezőgazdasági tudomány vívmányaival el lehet érni.

Ennek a rendkívül nagyarányü elmaradásnak természetesen nemcsak mezỏgazdasági tudományunkban, növénytermelésünk kutatómunkájában van az oka. A legfőbb oka az, hogy sem a régi kapitalista nagyüzemi gazdálkodás, sem a kisparcellás paraszti gazdálkodás nem volt alkalmas és képes arra, hogy nagy arányban felhasználja a tudomány vívmányait és ezek segítségével folyamatosan és nagy mértékben emelje a növénytermelés hozamát. Emellett azonban régi növénytermelési tudományunknak is része van abban, hogy országunk termésátlagai a XIX. és XX. század fordulója óta lényegében alig növekedtek. Ez a tudomány, bár kitünő kutatók jelentôs és érdemes eredményeket értek el, a kapitalista világ tudománya volt, olyan formalista mezőgazdasági tudomány, amely álproblémák és üres formalista elvi kérdések feszegetésábe ölte legtöbb energiáját és a termelékenység növelésének legfőbb igazi kérdéseit szem elöl tévesztette. Ezek az okok teszik érthetővé, hogy termésátlagaink szégyenletesen alacsonyak, noha dolgozó parasztságunk szorgalmas és tanulékony, s képes arra, hogy a fejlettebb agrotechnikai módszereket elsajátítva, a termelés szintjét hatalmas arányokban emelje.

Országunk felszabadulása és mezőgazdaságunk szocialista építése nyitotta meg az útját annak, hogy növénytermelésünk termelékenységét jelenlegi tủrhetetlen alacsony szintjérôl elmozdítsuk és a tudomány eredményeinek alkalmazásával, fejlettebb agrotechnikai módszerekkel, mind jobb és jobb növényfajták bevezetésével évről évre magasabb fokra emeljük.

Szocialista nagyüzemeink már jelentōs területet foglalnak el országunk szántóföldjéből és ezen a területen a szocialista nagyüzemi termelés már megteremtette a legfőbb feltételeit a magasabb tormésredmények elérésének. Egyidejüleg az élenjáró szovjet mezőgazdasági tudomány és gyakorlat példájának a megtermékenyítő hatása nyomán, mezőgazdasági tudományunk is megindult a fejlödés útján. Ily módon az elmult néhány év munkájában már jelentős eredményeket értünk el. Ezek az eredmények azonban még csak biztató kezdeti lépźssk, nem pədig olyan valóságos eredmények, amelyek máris jelentősen emeltśk volna növénytormelésünk termelékenységát, az egyes növények terméshozamát. Mezőgazdasági tudományunk elsősorban a növénytermelés terén hatalmas lépést tett elổre a micsurini-liszenkói biológia alap- 
jain és elindult azon az úton, amelyen képessé válik arra, hogy valóságos segítséget nyujtson növénytermelésünk színvonalának emelésében. $\mathrm{Az}$ eredményeik azonban még nagyon kezdetlegeselk és a tudományos kutató munkánk módszerei sem állanak még azon a fokon, hogy teljes sikerrel és gyors eredményekkel szolgálhatná a\% elérendő célt.

A természet átalakításának a lehetőségei határtalanok és a micsurini-liszenkói alapokra támaszkodó mezőgazdasági tudomány képes arra, hogy e határtalan lehetỏségeket lépésrỏl lépésre realizálja. A kérdést ma a mi országunkban úgy kell feltenni, hogy a hatalmas arányokban növekvő szocialista nagyïzemi gazdálkodás alapjain növénytermelésünk termelékenységét milyen mértékben képes a lehető leggyorsabban növelni mezőgazdasági tudományunk. Semmi kétség nem lehet afelől, hogy lehetséges ezt a növelést tudományosan kiszámítani és ennek alapján a maihoz viszonyítva, szinte hihetetlenül magas terméseredmények elérését lehet számszerüen célul kitüzni. Azonban minden különösebb számitás nélkül is bátran állitható, hogy nincs növénytermelésünknek olyan ága, amelyben a szocialista nagyüzem alapjain a micsuriniliszenkói mezögazdasági tudomány vívmányainak alkalmazásával a terméshozamot ne lehetne legalább kétszeresére emelni. Ez ma szocializmust építö országunkban reális és szükséges célkitïzés és ennek a megvalositúsát nem beláthatatlan idöre, hanem belátható idö távlatában célul kell kitüzni mezögazdaságunk elé.

E hatalmas arányú, de teljes mértékben megvalósítható feladat elérésének minden jelentös tényezőjét ismerjük. Nemcsak minden tudományos kutató, hanem minden valamennyire is képzett agronómus pontosan tudja, hogy kísérleti gazdaságainkban, élenjáró állami gazdaságainkban, sôt termelöszövetkezeteink ben is mely tényezökön múliłk az, hogy a terméshozamot általában a mainak kétszeresére emeljük. Az alapvető agrotechnikai módszerek, a trágyázás fejlesztése, a növényfajták javítása és nemesítése, s együttesen a füves vetésforgós rendszer fokozatos bevezetése azok az eszközök, amelyek helyes kidolgozásával és fejlesztésével ezt a célt elérhetjük.

Mezőgazdasági tudományunk számára tehát a növénytermelésben ezt a feladatot kell elérendő célul kitüzni, s ezt a célt annál inkább kitűzhetjük, mert mindazok a feltételek, amelyek eléréséhez szïkségesek, teljes mértékben rendelkezésünkre is állanak.

$\mathrm{Az}$ élenjáró szovjet mezőgazdasági tudomány és gyakorlat eredményei, a micsurini-liszenkói biológiai elméleti útmutatása az alap és a legfőbb forrás, amely felfegyverzi mezongazdasági tudományunkat arra, hogy ilyen feladat mego'dásához sikerrel hozzálásson és néhány év alatt kézzelfogható, valósá gos eredményeket érjen e].

Nem szabad lebecsülnünk azt a feltételt sem, ami rígi tapasztalt kutatóink gyakorłatában és eddig elért eredményeikben rendelkezésünk re áll. Országunk ta]ajviszonyainak, növényállományának és növényfajtáinak a mélyrehajtó és komoly ismerete, egyes eddig kido'gozott módszerek nagyobb arányú felhasználása, s általában eddigi tapasztalataink fejlesztése és szélesłc̈rü elterjeszt'se, mind o'yan eszközök. amelyek magukban véve is jelentős tényezöi tərméshozamunk emelésének.

De támaszkodhatunk azokra a tapasztalatokra is, amelyeket országunk minden részén do'gozó parasztságunk szerzett és azok at kisobb-nagyobb körben alkalmazza. A termelők élenjáró tapasztalatai a régebbi időkből is, de most a szocialista gazdaságokban különösen kimeríthetetlen forrásként már nemcsak csörgedeznek, hanem szinte áradnak. A mezőgazdasági tudomány feladata ezeket felismerni, felhasználni és fejleszteni.

Mezőgazdasági tudományunk ma igen sok és jelentős módszeri, elméleti kérdésekben fejt ki erőfeszít'́seket és ér is el kisebb-nagyobb eredményeket. A legnagyoib tévedés lenne azonban azt hinni, hogy növénytermelési tudományunk igazán jelentős elméleti vagy módszeri eredményt érhet el, ha minden erejćt nem közvetlenül a terméshozamok emelésére, a termelékenység növelésének a mego'dására fordítja. Az élen- 
járó szovjet mezőgazdasági tudomány minden példája, ezek között is kiemelkedően Liszenko akadémikus személyes példája, a lenyügözö erejü bizonysága annak, hogy igazán jelentős tudományos eredmény, elméleti és módszeri elörehaladás csak a legközvetlenebb gyakorlati eredmények kiharcolása, a terméshozamok látható, valóságos emelése utján érhető el.

Mezőgazdasági tudományunk számára szocializmust építő országunk, a Párt és az állam gondoskodása olyan feltételeket teremtett, amelyekről a régebbi idökben álmodni sem mertek kutatóink. Dolgozó parasztságunk kezdeményezése, alkotó erejének nagyarányú kibontakozása szintén olyan mértékben nyilvánul meg ma a termelés fejlesztésében, amilyen mértékben soha országunkban mezögazdasági tudomány előrehaladását, a gyakorlat még nem segítette. És ami a legfőbb : a tudomány gyakorlatban alkalmazható vívmányait ma feszült várakozással lesi termelésünk gyakorlata és minden valóban használható új eredményt azonnal tömegesen alkalmaz a gyakorlatban.

Ez a folyóirat, amely most megindul, újabb fegyver a kezünkben, hogy mind világosabbá és kézzelfoghatóbbá tegye mezőgazdasági tudományunknak ezeket a feladatait és sagítse azon az úton, hogy a tudomány egyetlen és igazi feladatát gyorsan és sikeresen megoldja.

\title{
ВАЖНЕЙИИ ЗАДАНИЯ НАУКИ В ОБЛАСТИ РАСТЕНИЕВОДСТВА
}

ЕРДЕИ Ф.

министр земледелия

Резюме

ІІрименением научных методов Мичурина-Јысенко валовую продукцию нашего сельского хозяйства можно повысить в два раза. Задача науки заключается в том, чтобы обеспечивать постоянное развитие производства. Наши крупные коллективные хозяйства ожидают новых научных достижений, чтобы применять их на практике. Перед этим журналом поставлена задача развертывать науку по растениеводству, содейсгвуя тем самым и процветанию практической работы в области растениеводства.

\section{The Most Important Task of Science in Our Crop Production}

\author{
F. ERDEI
}

Minister of Agriculture

\section{Summary}

We can double our agcicultural production in using the science of Michorrin and Lysenko. It is the task of soience to assure the constant $\mathrm{d}^{\rho} \mathrm{v}$ olopment of production. Our big agricultural cooperatives wait for the new scientifical results to put them into practice. The task of our journal is to develop the applied agricultural sciences and to help agriculture. 


\section{Die wichtigsten Aufgaben der Wissenschaft in unserem Pflanzenbau}

F. ERDEI

Ackerbauminister

Zusammenfassung

Durch Anwendung der mitschurinisch-lysenkoischen Wissenschaft kann unsere Ackerbauproduktion verdoppelt werden. Die Aufgabe der Wissenschaft ist die ständige Entwicklung der Produktion zu sichern. Unsere grossen Kollektivwirtschaften warten auf die neuen wissenschaflichen Ergebnisse um sie in die Praxis umzusetzen Die Aufgabe dieser Zeitschrift ist die angewandte Agrarwissenschaft zu fördern und den Pflanzenbau im Alltag zu unterstiitzen.

\section{Le devoir le plus important de la science dans notre production végétale}

F. ERDEI

Ministre de l Agriculture

Résumé

Il nous est possible de redoubler notre production agricole en appliquant la science de Mitchourine et de Lysənko. Le devoir de la science est d'assurer le développement permanent de la production. Nos coopératives agronomique attendent les nouveaux résultats scientifiques pour les utiliser dans la pratique. Notre journal tient pour but de développer les sciences agricoles appliquées et de preter aide á la pratique agricole. 